Revista Eletrônica Geografar, Curitiba, v. 2, Resumos do VI Seminário Interno de Pós-Graduação em Geografia, p. 13-13. Junho/2007

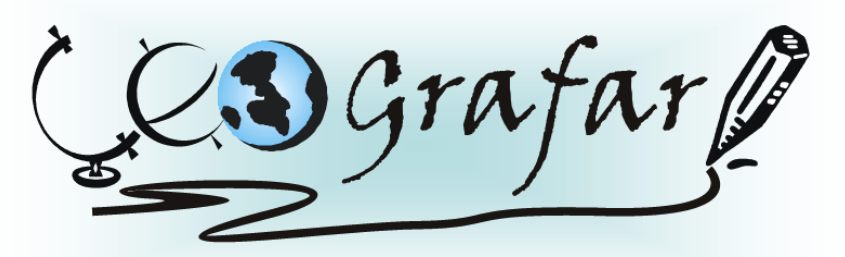

Revista Eletrônica do Programa de Pós-Graduação em Geografia - UFPR

\title{
ANÁLISE SISTÊMICA DA DINÂMICA DA BACIA HIDROGRÁFICA DO RIO IRAÍ (PR): PROCESSOS DE EROSÃO, DESLIZAMENTOS E ENCHENTES
}

\author{
CLAUDINEI TABORDA DA SILVEIRA ${ }^{1}$
}

Compreendendo a bacia hidrográfica como um sistema aberto, segundo os fundamentos da Teoria Geral dos Sistemas e do Geossistema, a presente pesquisa tem como objetivo fazer a análise sistêmica da dinâmica dos processos hidrológicos e a influência dos seus componentes biológicos, geomorfológicos e pedológicos. Avaliando a estrutura, organização e funcionalidade nesse sistema ambiental, cujo imput se dá pela ação climática: recebimento de calor do sol e água das chuvas, resultando, após a dinâmica dos componentes e trocas de energia, em sedimentos e solutos como output. Segundo essa compreensão, as alterações no suporte biológico, identificadas pelo uso do solo, interferem na cobertura pedológica e no relevo, que refletem diretamente sobre a infiltração da água, seu armazenamento e conseqüentemente no fluxo de escoamento; mudanças nesses processos, que são dinâmicos e inter-relacionados, alteram as trocas de energia em toda a organização do sistema. Assim, essas fases serão avaliadas como subsistemas integrantes do sistema aberto e dinâmico da bacia do rio Irai, que representa a área de estudo. A área adotada como objeto da pesquisa foi eleita por apresentar características físico-naturais potenciais para a ocorrência de processos de erosão, deslizamentos e enchentes, também porque tal bacia compõe uma paisagem de grandes transformações antrópicas, localizada na Região Metropolitana de Curitiba, além de conter um dos importantes reservatórios de água para abastecimento público, a Represa do Iraí. Os primeiros ensaios físicos realizados na bacia foram: alteração da capacidade de infiltração da água e armazenamento no solo pelo uso antrópico, identificando modificações nas propriedades estruturais do solo tal como a porosidade e índice de vazios e a camada de matéria orgânica; simulação de erosão por fluxo hídrico no aparelho Inderbitzen, que apresenta valores comparativos de perda de sedimentos; e analise textural de amostras de solos.

Palavras Chave: bacia hidrográfica, sistema, rio Iraí.

1Doutorando em Geografia - UFPR - email: claudineits@pop.com.br Orientadora: CHISATO OKA-FIORI 